\title{
QUANTITATIVE HISTOCHEMISTRY OF THE NEPHRON. III. LACTIC DEHYDROGENASE ACTIVITY IN MAN AND OTHER SPECIES *
}

\author{
By SJOERD L. BONTING, VICTOR E. POLLAK, $\dagger$ ROBERT C. MUEHRCKE \\ AND ROBERT M. KARK \\ (From the Departments of Biological Chemistry and Medicine, University of Illinois College of \\ Medicine, and Departments of Medicine, Presbyterian-St. Luke's Hospital, Cook County \\ Hospital, and Research and Educational Hospitals, Chicago, Ill.)
}

(Submitted for publication March 25, 1960 ; accepted April 22, 1960)

In previous papers $(1,2)$ we have described observations on the quantitative distribution of alkaline phosphatase in the anatomical units of the nephron in man and other species. This enzyme was selected for study by microdissection of lyophilized sections of kidneys and ultra-microassay because there was considerable information available on its qualitative distribution in the nephron. In particular, the known qualitative differences in its distribution in the proximal and distal convolutions of the tubule allowed us to verify the accuracy of the microdissection technique we used (2). Once this was accomplished we were able to study the quantitative distribution of other enzymes for which less information was available. In this paper the results of assay of lactic dehydrogenase $(\mathrm{LDH})$ activity on renal tissues from healthy humans and laboratory animals are reported. LDH was chosen for study because it plays an important role in energy metabolism, namely, in the glycolytic formation of lactic acid and in its mobilization for complete oxidation in the tricarboxylic acid cycle. As far as could be ascertained, no data were available on its distribution or functional significance in the cells of the nephron.

\section{METHODS}

Handling of tissue. In previous communications $(1,2)$ we have described in detail the techniques used for dissecting, weighing, and enzyme assay of the individual units of the nephron.

$L D H$ assay. Optimal conditions for assay of $\mathrm{LDH}$ activity in the human kidney were determined (Table I). Tissue samples with a dry weight ranging from 10 to 100

* Supported in part by grants from the Surgeon General's Office, U. S. Army (Contract no. DA-49-007-MD$637)$ and the National Institutes of Health, Bethesda, Md. (H-3058 and H-3912).

$\dagger$ Established Investigator, American Heart Association, supported by the Illinois Heart Association. $\mathrm{m} \mu \mathrm{g}$ were inserted into $10 \mu \mathrm{l}$ of a substrate medium containing $1.0 \mathrm{mM}$ sodium pyruvate, $1.25 \mathrm{mM}$ reduced diphosphopyridine nucleotide (DPNH, Sigma), $25 \mathrm{mM}$ nicotinamide, and 0.05 per cent bovine serum albumin (Armour) in $0.2 \mathrm{M}$ Tris buffer, $\mathrm{pH}$ 7.15. After incubation for 30 minutes at $37^{\circ} \mathrm{C}$ the reaction was stopped and the excess DPNH destroyed by adding $2 \mu 11.0 \mathrm{~N} \mathrm{HCl}$. A $10 \mu \mathrm{l}$ aliquot was then transferred to a $75 \times 10 \mathrm{~mm}$ Pyrex tube containing $100 \mu l 6.5 \mathrm{~N} \mathrm{NaOH}$ and incubated for 30 minutes at $37^{\circ} \mathrm{C}$. The oxidized DPN formed by enzyme action during the first incubation period was thereby converted into a fluorescent substance (3). After dilution of the resulting solution with $1.0 \mathrm{ml} \mathrm{H}_{2} \mathrm{O}$ the fluorescence was determined in a Farrand filter fluorimeter (primary filter, Corning glass color filter no. 5860; secondary filters, Corning nos. 4308, 5562, 3387). All readings were made against a quinine standard $(0.25 \mu \mathrm{g}$ per $\mathrm{ml}$ ). The results were expressed in moles of DPNH oxidized per hour at $37^{\circ} \mathrm{C}$ per kilogram dry weight of tissue (MKH units).

Effects of dry and wet "canning" on LDH activity. Because Lowry, Roberts and Chang (4) have shown that the method of "canning" (i.e., the act of inserting lyophilized cells or tissue fragments into the microtest tubes prior to incubation) may affect enzyme assays, we studied the effects of two methods of canning on the assay of $\mathrm{LDH}$. In dry canning the weighed tissue fragments were inserted into clean dry microtest tubes. The rack

TABLE I

Properties of lactic dehydrogenase in the human kidney

\begin{tabular}{|c|c|c|}
\hline Michaelis-Menten constant & $\begin{array}{l}\text { Pyruvate } \\
\text { DPNH }\end{array}$ & $\begin{array}{l}0.20 \mathrm{mM} \\
0.11 \mathrm{mM}\end{array}$ \\
\hline $\begin{array}{l}\text { Optimal substrate concen- } \\
\text { tration }\end{array}$ & $\begin{array}{l}\text { Pyruvate } \\
\text { DPNH }\end{array}$ & $\begin{array}{l}1.0 \mathrm{mM} \\
2.5 \mathrm{mM}\end{array}$ \\
\hline Optimal pH & \multicolumn{2}{|l|}{7.15} \\
\hline $\begin{array}{l}\text { Activity vs incubation time } \\
\left(37^{\circ} \mathrm{C}\right)\end{array}$ & \multicolumn{2}{|c|}{ Linear 0 to 120 minutes } \\
\hline $\begin{array}{l}\text { Activity vs enzyme concen- } \\
\text { tration }\end{array}$ & \multicolumn{2}{|c|}{$\begin{array}{l}\text { Linear between } 0.0 \text { and } 0.35 \\
\text { mmole/hour } / \mathrm{L} \text { of incu- } \\
\text { bation mixture }\end{array}$} \\
\hline $\mathrm{V}_{2}{ }^{\circ} \mathrm{c} / \mathrm{V}_{37^{\circ}} \mathrm{c}^{*}$ & \multicolumn{2}{|l|}{0.036} \\
\hline
\end{tabular}

${ }^{*} \mathrm{~V}=$ velocity of the enzyme reaction at the temperatures given. 
TABLE II

The effect of the method of "canning" on the lactic dehydrogenase activity*

\begin{tabular}{|c|c|c|c|c|c|c|}
\hline \multirow[b]{2}{*}{ Structure analyzed } & \multicolumn{3}{|c|}{ Monkey } & \multicolumn{3}{|c|}{ Dog } \\
\hline & Wet & Dry & $\frac{\text { Dry }}{\text { Wet }} \times 100$ & Wet & Dry & $\frac{\text { Dry }}{\text { Wet }} \times 100$ \\
\hline Glomerulus & $\begin{array}{l}55 \pm 5.6 \\
{[13]}\end{array}$ & $\begin{array}{c}44 \pm 5.8 \\
{[13]}\end{array}$ & 80 & $\begin{array}{c}82 \pm 9 \\
{[6]}\end{array}$ & $\begin{array}{c}70 \pm 4 \\
{[5]}\end{array}$ & 85 \\
\hline Proximal convoluted tubules & $\begin{array}{l}78 \pm 4.2 \\
{[13]}\end{array}$ & $\begin{array}{c}78 \pm 4.9 \\
{[14]}\end{array}$ & 100 & $\begin{array}{c}353 \pm 2.7 \\
{[5]}\end{array}$ & $\begin{array}{c}151 \pm 20 \\
{[8]}\end{array}$ & $43 \dagger$ \\
\hline Distal convoluted tubules & $\begin{array}{c}116 \pm 10.6 \\
{[13]}\end{array}$ & $\begin{array}{l}90 \pm 8.2 \\
{[10]}\end{array}$ & 78 & $\begin{array}{c}366 \pm 37 \\
{[6]}\end{array}$ & $\begin{array}{c}252 \pm 31 \\
{[4]}\end{array}$ & $68 \dagger$ \\
\hline Medullary ray & $\begin{array}{c}137 \pm 6.6 \\
{[26]}\end{array}$ & $\begin{array}{c}143 \pm 6.6 \\
{[18]}\end{array}$ & 104 & $\begin{array}{c}316 \pm 14 \\
{[12]}\end{array}$ & $\begin{array}{c}127 \pm 6.1 \\
{[6]}\end{array}$ & $40 \dagger$ \\
\hline Outer medullary zone & $\begin{array}{c}171 \pm 11.0 \\
{[10]}\end{array}$ & $\begin{array}{c}167 \pm 20.4 \\
{[8]}\end{array}$ & 98 & $\underset{[6]}{280 \pm 11}$ & $\begin{array}{l}63 \pm 6.7 \\
{[8]}\end{array}$ & $22 \dagger$ \\
\hline Inner medullary zone & $\begin{array}{c}146 \pm 5.5 \\
{[18]}\end{array}$ & $\underset{[4]}{135 \pm 5.0}$ & 93 & $\begin{array}{c}125 \pm 6.5 \\
{[6]}\end{array}$ & $\underset{[6]}{43 \pm 2.5}$ & $34 \dagger$ \\
\hline Papilla & $\begin{array}{c}63 \pm 4.6 \\
{[10]}\end{array}$ & $\underset{[4]}{27 \pm} 6.5$ & $43 \dagger$ & $\begin{array}{c}39 \pm 3.5 \\
{[10]}\end{array}$ & $\begin{array}{c}16 \pm 4.5 \\
{[10]}\end{array}$ & $41 \dagger$ \\
\hline Vessel & $\begin{array}{c}51 \pm 5.4 \\
{[13]}\end{array}$ & $\begin{array}{c}44 \pm 4.4 \\
{[12]}\end{array}$ & 86 & $\begin{array}{c}22 \pm 0.6 \\
{[3]}\end{array}$ & $\begin{array}{c}10 \pm \\
{[6]}\end{array}$ & $45 \dagger$ \\
\hline
\end{tabular}

* Expressed in moles DPNH oxidized per hour at $37^{\circ} \mathrm{C}$ per kilogram dry weight. The total number of specimens of each structure analyzed is given in brackets.

† Significantly below 100 at 0.05 level.

with tubes was placed in an ice bath and the incubation medium was then added. In wet canning the weighed tissue specimens were inserted directly into the substrate medium previously pipetted into microtest tubes, which were kept in an ice bath until all specimens had been inserted.

Intracellular distribution of $L D H$ activity. The intracellular distribution of LDH activity was also studied because we were unable to find such data in the literature. A 10 per cent homogenate was made of whole rat kidney in $0.25 \mathrm{M}$ sucrose containing $1.8 \mathrm{mM} \mathrm{CaCl}_{2}$ and subjected to fractionation in the cold using a Spinco preparative ultracentrifuge (5). The resulting fractions were assayed for LDH activity. The nuclear fraction was prepared by layering $6 \mathrm{ml}$ homogenate on $4 \mathrm{ml} 0.34 \mathrm{M}$ sucrose containing $0.18 \mathrm{mM} \mathrm{CaCl}$ and centrifuging at $100 \times \mathrm{G}$ for 10 minutes. The mitochondrial fraction was isolated by centrifuging the supernatant at $5,000 \times \mathrm{G}$ for 10 minutes; the sediment was washed, resuspended, and centrifuged for 10 minutes at $24,000 \times \mathrm{G}$. The microsomal fraction was prepared from the supernatant remaining after sedimentation of the mitochondrial fraction by centrifugation for 1 hour at $50,000 \times \mathrm{G}$. The supernatant remaining after this centrifugation was the supernatant fraction.

\section{Technical}

\section{RESULTS}

Table II shows the effects of two methods of "canning" on LDH activity. From this it is clear that the wet canning method gave significantly higher results for LDH activity than did the dry canning method in half of the cases. The wet canning technique was therefore adopted as a routine, and the incubation was carried out directly after the canning was completed.

\section{Experimental}

Intracellular distribution. Data on LDH assay in the fractions of renal homogenates are given in Table III. It can be seen that 93.3 per cent of the LDH activity was found in the supernatant fraction, while the total for the activities of the individ-

TABLE III

The intracellular distribution of lactic dehydrogenase in whole rat kidney homogenates *

\begin{tabular}{lc}
\hline \hline \multicolumn{1}{c}{ Fraction analyzed } & $\begin{array}{c}\text { Percentage of activity } \\
\text { in homogenate }\end{array}$ \\
\hline Homogenate & $100 \pm 0.26$ \\
Nuclear fraction & $1.15 \pm 0.40$ \\
Mitochondrial fraction & $6.60 \pm 1.90$ \\
Microsomal fraction & $3.35 \pm 0.71$ \\
Supernatant fraction & $93.3 \pm 1.8$ \\
Total & $104.4 \pm 2.7$
\end{tabular}

* These are combined results from 3 separate fractionations on 6 rat kidneys, each fraction being analyzed in triplicate.

t Results are mean values with standard errors of the mean. 
TABLE IV

Lactic dehydrogenase activity in the anatomical units of nephrons from healthy kidneys in man and various animal species (expressed in moles of DPNH oxidized per kilogram dry weight of tissue per hour at $37^{\circ} \mathrm{C}$ ) *

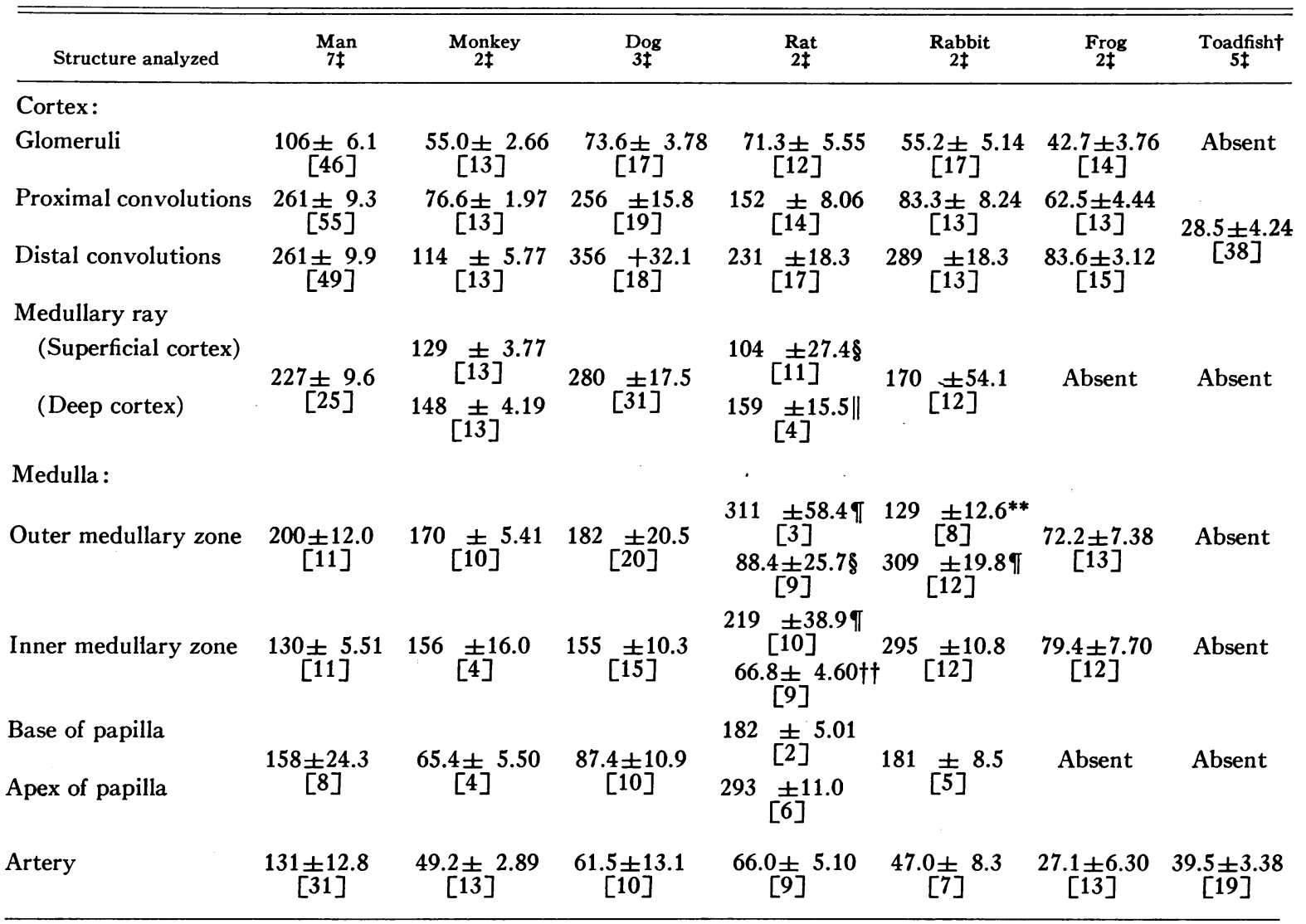

* Results are expressed as mean values with the standard error of the means. The total number of specimens of each structure analyzed is given in brackets.

†Toadfish, convoluted tubules only; lymphoid tissue $=83.4 \pm 2.99[42]$; Wolff canal $=67.3 \pm 4.07 \mathrm{MKH}$ units [37].

t Total number of kidneys analyzed.

Light: pars recta and collecting tubules.

II Dark: distal convolutions.

II Dark: ascending loop of Henle.

** Light: descending loop of Henle and collecting tubules.

†† Light: collecting tubules.

ual fractions was very close to the activity of the whole homogenate.

Individual nephrons. LDH activity was assayed in the individual units of the nephron of man, monkey (Macacca mulatta), dog (mongrel), rat (Sprague-Dawley), rabbit (New Zealand white), frog (Rana pipiens), and aglomerular toadfish (Opsanus tau). The results are shown in Table IV. The number of individuals or animals studied and the number of fragments analyzed are given, together with the mean values and standard error of the means. The quantitative distributions are shown diagrammatically in Figure 1.
The over-all level of LDH activity was high, being approximately from 10 to more than 100 times the activity obtained for alkaline phosphatase (2).

In man no difference was found between the LDH activities in the proximal and distal convoluted tubules. In all other species the activity in the distal convoluted tubules was greater than that in the proximal convoluted tubules. The levels of activity found in the medullary tubules were comparable to those in the cortical tubules. Except for the vessels, the lowest LDH activity was found in the glomeruli of all species. 


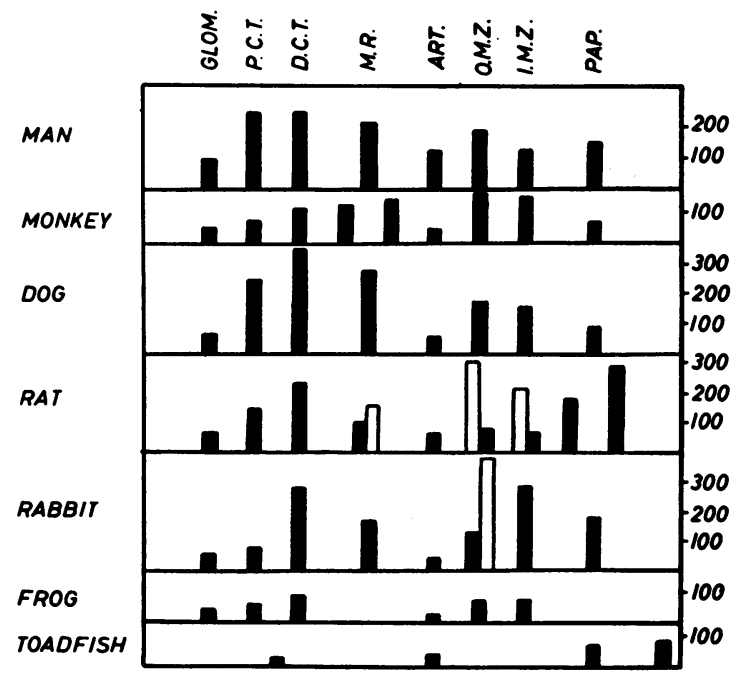

Fig. 1. The Quantitative Distribution of Lactic DEH YDROGENASE ACTIVITY (LDH) IN THE NEPHRON. The bars represent mean $\mathrm{LDH}$ activities expressed in moles of DPNH split per kilogram dry weight of tissue per hour at $37^{\circ} \mathrm{C}$. (See text and Table IV for details.)

After the experiments reported here were completed, further assays of $\mathrm{LDH}$ activities were made in our laboratory. All the results obtained were from 29 to 42 per cent of those reported in Table IV; however, the distribution and ratio of $\mathrm{LDH}$ activity in the individual units of the nephron remained the same. The over-all decrease in LDH activity was found to coincide with the use of a new batch of DPNH (Sigma). An investigation planned to find the cause of the discrepancy was seriously handicapped by the fact that none of the first batch of DPNH was available for study. However, a thorough study was made of all possible causes of inhibition of LDH activity which suggested themselves to us.

Whereas with the first batch of $\mathrm{DPNH}$ the $\mathrm{LDH}$ activity in the rat glomerulus was 71.3 $\pm 5.55 \mathrm{MKH}$ units, the activity found in the new batch of DPNH was $29.3 \pm 2.71 \mathrm{MKH}$ units, i.e., a ratio of 2.42 to 1 . Similarly, the LDH activity of normal human glomeruli was found to be 106 and $30.8 \mathrm{MKH}$ units with the first and second batches of DPNH, respectively, i.e., a ratio of 3.45 to 1 . Recently Dubach and Recant have published a value of $26.6 \pm 3.0 \mathrm{MKH}$ units for the rat glomerulus (6), which agrees closely with values for $\mathrm{LDH}$ activity we are getting at present. This might suggest either that an inhibitor of renal LDH activity was present in the second batch of
DPNH, or that an activator was present in the first batch.

\section{DISCUSSION}

Technique. Since higher results were obtained with the wet canning technique than with the dry canning technique, wet canning was employed in all the LDH assays. Lowry and associates have shown that the loss of activity in the dry canning technique was due to condensation of water on the small fragment of tissue before the incubation medium was added (4). Two sets of experiments were performed to compare the effects of the two canning methods. The experiment on monkey kidney was done while the relative humidity was 10 per cent. The loss of activity in the dry canning method did not exceed 22 per cent, except in the case of the papilla, which was in the ice bath for the longest period before the reagent was added. The experiment was done on dog kidney while the relative humidity was 25 per cent; the loss of LDH activity in the dry canning method was significant in all structures except the glomeruli, and exceeded 50 per cent in all but two structures. These data confirm Lowry and co-workers' suggestion (4) that condensation of water on the minute specimen is the important factor in the loss of enzyme activity in the dry canning method. It also seemed possible that the humidity of the atmosphere might affect the enzyme activity during the 2 to 3 hours' exposure of the tissue prior to canning, i.e., during dissection and weighing. For this reason we compared the activities found in proximal and distal convoluted tubules for normal man with the relative humidity prevailing when the experiments were done. Over a range of relative humidity from 22 to 40 per cent no correlation existed between the humidities prevailing and the LDH activities.

One further factor which might possibly influence the results is the length of storage of the tissue sections prior to assay. We found that storage up to six months of the frozen-dried tissue sections in vacuo at $-35^{\circ} \mathrm{C}$ did not influence the enzyme activity. This is in accord with the results reported by Strominger and Lowry (7).

The validity and reproducibility of the quantitative histochemical technique used in these experiments (1) have been demonstrated by Lowry and associates (8). The sample size used in our stud- 
ies was of the order of 15 to $100 \mathrm{~m} \mu \mathrm{g}$, which is slightly larger than that used by Lowry and coworkers in their study of single brain cells ( 8 to 25 $\mathrm{m} \mu \mathrm{g}$ ) (4). The average relative standard error of the mean in all our experiments was 8.3 per cent. This value is comparable to the average relative standard error of the mean (10.5 per cent) for three different enzymes studied by Lowry and colleagues.

Experimental. The results for $\mathrm{LDH}$ activity were much higher on a molar basis than those found for alkaline phosphatase in the same species (2), and also higher than those found for aldolase, fumarase, hexokinase, and phosphohexoisomerase in the dog kidney (9). Thus, assuming these measurements quantitatively reflect activity in vivo, it seems unlikely that LDH is a rate-limiting enzyme in the glycolytic system in any part of the nephron.

LDH was more evenly distributed throughout the units of the nephron than was alkaline phosphatase. The lowest levels of $\mathrm{LDH}$ activity were found in the glomeruli. This appears to be part of a general pattern emerging from the data reported by McCann for aldolase, fumarase, hexokinase and phosphohexoisomerase in the dog kidney (9), and from our own unpublished results with glucose-6-phosphatase, adenosine triphosphatase and hexokinase (10).

The finding that LDH is almost exclusively located in the nonparticulate cytoplasm is noteworthy in view of the fact that the enzymes of the Krebs cycle have been located principally in the mitochondria $(11,12)$, whereas the nonparticulate cytoplasm contains the glycolytic system (11). This would mean that it is necessary for lactic acid to be oxidized to pyruvic acid in the nonparticulate cytoplasm before entering the Krebs cycle in the mitochondria.

\section{SUM MARY}

1. The quantitative distribution of lactic dehydrogenase (LDH) activity in the nephron of man, monkey, dog, rat, rabbit, frog and toadfish was studied.

2. Considerable LDH activity was found in all parts of the nephron analyzed. In all cases the cortical tubules had higher activity than did the glomeruli. The highest levels of activity were found in the nephrons of man and dog, the lowest in the frog and the toadfish.

3. Within the cell, LDH activity was found almost exclusively in the nonparticulate cytoplasm.

\section{ACKNOWLEDGMENT}

We wish to thank Miss Alta D. Tsoodle, Mrs. Hendrina deBruin and Mr. Bart R. Mayron for technical assistance.

\section{REFERENCES}

1. Bonting, S. L., Pollak, V. E., Muehrcke, R. C., and Kark, R. M. Quantitative histochemistry of the nephron. Science 1958, 127, 1342.

2. Bonting, S. L., Pollak, V. E., Muehrcke, R. C., and Kark, R. M. Quantitative histochemistry of the nephron. II. Alkaline phosphatase activity in man and other species. J. clin. Invest. 1960, 39, 1372.

3. Lowry, O. H., Roberts, N. R., and Kapphahn, J. I. The fluorometric measurement of pyridine nucleotides. J. biol. Chem. 1957, 224, 1047.

4. Lowry, O. H., Roberts, N. R., and Chang, M. L. The analysis of single cells. J. biol. Chem. 1956, 222, 97.

5. Hogeboom, G. H. Fractionation of cell components of animal tissues in Methods in Enzymology, S. P. Colowick and N. O. Kaplan, Eds. New York, Academic Press, 1955, vol. I, p. 16.

6. Dubach, U. C., and Recant, L. Enzymatic activity of the isolated glomerulus in normal and nephrotic rats (abstract). J. Lab. clin. Med. 1959, 54, 808.

7. Strominger, J. L., and Lowry, O. H. The quantitative histochemistry of the brain. IV. Lactic, malic and glutamic dehydrogenases. J. biol. Chem. 1955, 213, 635.

8. Lowry, O. H., Roberts, N. R., Wu, M. L., Hixon, W. S., and Crawford, E. J. The quantitative histochemistry of the brain. II. Enzyme measurements. J. biol. Chem. 1954, 207, 19.

9. McCann, W. P. Quantitative histochemistry of the dog nephron. Amer. J. Physiol. 1956, 185, 372.

10. Bonting, S. L., deBruin, H., and Tsoodle, A. Quantitative histochemistry of the nephron. VII. The properties and assay of various phosphatases in the human kidney. In preparation.

11. Kennedy, E. P., and Lehninger, A. L. Oxidation of fatty acids and tricarboxylic acid cycle intermediates by isolated rat liver mitochondria. J. biol. Chem. 1949, 179, 957.

12. Green, D. E. The cyclophorase system in Enzymes and Enzyme Systems: Their State in Nature, J. T. Edsall, Ed. Cambridge, Mass., Harvard University Press, 1951, p. 15. 